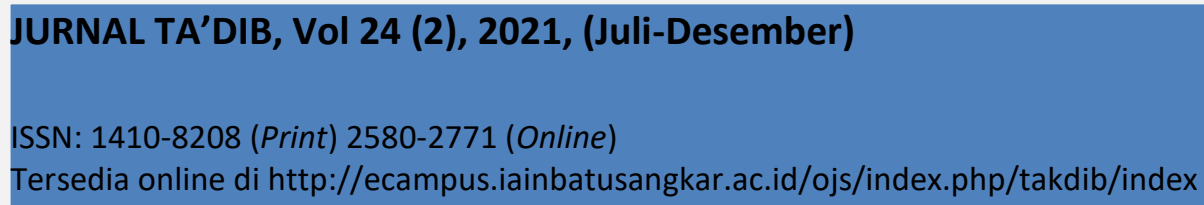

\title{
The Syuro-Participative Leadership in Al-Qur'an-Based Pesantren in the Disruption Era
}

Received:13-02-2021; Revised: 29-10-2021; Accepted: 01-11-2021

Muh. Mustakim*)

Universitas Alma Ata, Yogyakarta, Indonesia

E-mail: muh.mustakim@almaata.ac.id

\section{Ahmad Salim}

Universitas Alma Ata, Yogyakarta, Indonesia

E-mail: ahmadsalim0305@almaata.ac.id

\section{Kana Safrina Rouzi}

Universitas Alma Ata, Yogyakarta, Indonesia

E-mail: kanasafrina@almaata.ac.id

\section{Ruwet Rusiyono \\ Universitas Alma Ata, Indonesia \\ E-mail: ruwet.rusiyono@almaata.ac.id}

\section{Desy Khusna Nurmaida \\ Universitas Alma Ata, Indonesia \\ E-mail: desykhusna4@gmail.com}

*) Corresponding Author

\begin{abstract}
This study discussed the renewal of leadership models in Al-Qur'an-based pesantren. Leadership in pesantren has a major influence on its development and existence. Ibn Abbas Islamic Boarding School is interesting to study because it is modern managed. This is a case study to examine in depth the developed leadership model. The data were collected through observation, documentation, and interview, and analyzed using the Miles Huberman triangulation model, so that the results were in the form of abstractions showing their novelty. Pesantren Ibnu Abbas Klaten is led by a director who acted as a manager as well as mufti and kyai. The director supervises three educational units; the pesantren, the santri, and the school unit, which each led by a chief. Even though a director (or Kyai) has full leadership rights, the "syuro-participative" leadership model is implemented in regular meetings every week, and the deliberation results showing the participation of each existing institution. This indicated that the highest forum is at the leadership meeting, not unilaterally by the Kyai.
\end{abstract}

\begin{abstract}
Abstrak: Tulisan ini mendiskusikan model kepemimpinan pesantren berbasis al-Qur'an. Kepemimpinan pesantren memiliki pengaruh besar bagi perkembangan dan eksistensinya. Pesantren berbasis al-Qur'an Ibnu Abbas sudah dikelola dengan manajemen modern. Penelitian kualitatif ini menggunakan studi kasus, pengumpulan data yang digunakan adalah metode observasi, dokumentasi dan interview. Sedangkan analisis data mengadopsi model trianggulasi Miles Huberman, sehingga hasil penelitiannya berupa abstraksi yang menunjukkan suatu kebaruan penelitian. Hasil penelitian menunjukkan bahwa pesantren Ibnu Abbas dipimpin oleh seorang direktur bertindak sebagai manajer sekaligus mufti (pemberi fatwa) atau disebut sebagai Kyai. Direktur membawahi tiga unit pendidikan yaitu unit pesantren, unit kesantrian dan unit sekolah yang masingmasing dipimpin oleh seorang kepala. Model kepemimpinan yang dikembangkan adalah model kepemimpinan "syuropartisipatif" hal ini terimplementasikan dalam pertemuan rutin disetiap pekannya, meskipun seorang direktur (atau Kyai) memiliki hak kepemimpinan secara penuh, namun cenderung mendahulukan hasil musyawarah yang terwakili dari partisipasi aktif masing-masing lembaga uinit. Temuan ini menunjukkan adanya pergeseran model kepemimpinan dari dominasi Kyai menjadi kepemimpinan collective collegial artinya forum tertinggi adalah rapat pimpinan bukan hanya oleh Kyai.
\end{abstract}

Keywords: Leadership, Pesantren, Syuro-participative. 


\section{INTRODUCTION}

$\mathrm{L}$ eadership in pesantren has a very important position and role in the existence of the oldest Islamic educational institution in Indonesia. Usually, pesantren is led by a director called Kyai, Buya, Ajengan, Teungku, Ustadz, or the like with traditional culture as the sole leader, although some pesantren have developed a collective leadership model (Supendi et al., 2019).

The development of modern leadership models is closely related to management, especially men, money, methods, materials, machines, and markets or termed the 6 (six) "M" as the main consideration in managing an organization or institution (Zubaidah, 2017; Sabir, 2017; Hasibuan, 2018).

The "men" as the main element of the pesantren managers can be Kyai, ustadh, pesantren administrators, and etc. The "money" element of pesantren is usually from the parents and donors even from the director. The "method" element is the learning proses with its own curriculum although some pesantren have now adopted modern learning models(Arif et al., 2016; Fuadi, 2020).

The "materials, machine, and market" element is identical to the management of pesantren related to the physical, development and adaptation to technological developments also the facilities which needed for the students who live in the pesantren every day. Pesantren has also adapted a lot to technology even though there are restrictions in some parts. In the marketing element, the pesantren is assisted by many students and the succeed alumni by word-of-mouth marketing (Jerry) but some pesantren also use the internet network. In addition to students, alumni and the community, some pesantren also use modern information systems to utilize the internet network (Anwas, 2015; Hermawan et al., 2014).

This phenomenon shows the pesantren transformation in such a way but still has its own characteristics. Therefore, the author proposed an indigenous transformation model as a typology of pesantren transformation, because pesantren is willing to adapt to developments but still strives with its own uniqueness (Mustakim, 2019).

\section{Disruption Era}

Linguistically, disruption means being uprooted from its roots (KBBI, 2017). Disruption is identical as chaos or disturbance describing a situation and condition in a society conditioned by information as an implication of technological progress so that it is transformed into an information society. Therefore, those who have the strongest and most access and are able to manage them well are potential "rulers" in this era. Technological developments affect major socio-economic changes so that a "big shock" is unavoidable (Ohoitimur, 2018).

Clayton Christensen (2020) had a different view, disruption from a financial industry and business perspective becomes profitable if managed properly. For example, in college. Even though the two views seem different, disruption is synonymous with a big change until it is uprooted from the roots or origins that have been running.

Renald Kasali (2015) explained that disruption is a different process or action so that it can disturb and cause shock. This era is synonymous with IoT (Internet of Things) and digitalization. The internet is the source of all information. In the digital era, those who are unwilling or unable to adapt are prepared to be left behind.

Rapid transformation in the disruption era has implications for various lines of life, including pesantren with the emergence of digital pesantren and the use of the internet or digitalization in management, learning, and leadership. If pesantren is reluctant to this reality, it is very likely that this Islamic educational institution will be left far behind from others. However, on the other hand, Islamic boarding schools have a moral and material responsibility to maintain indigenous values. Developments in the 
disruption era must be anticipated and managed properly and pesantren has long experience in dealing with various changes.

\section{Leadership Model}

"Model" means the way or pattern obtained from human behavior. "Leadership" is derived from the word "leader" or a person who tries to give or influence followers or members to realize the vision (KBBI, 2017; Sagala, 2018).

Leadership is often associated with influence while leaders are capable and have the potential to exert influence. In managing an organization or institution, leaders have an important role in influencing members to carry out the goals. Meanwhile, leadership is the process of directing people to be led and influenced to achieve common goals (Chaniago, 2017).

Chaniago explained that leadership will emerge if there are three factors influencing each other as stated by John Douglas namely people; situation; and organizational positions. An organization will run effectively if these three factors are well managed by the leader (Chaniago, 2017).

Leadership theory seeks to explain two main things, namely the various factors involved in the emergence of leadership and the nature of leadership. In the process of emerging leadership, whether leadership is prepared or what leadership is talent. The great man theory insists that great leaders are born not formed; someone who deserves to be a leader is born with the talent and ability to lead. Therefore, a great leader is born with charisma, intelligence, wisdom and the ability to make a big impact. This inherited or innate leadership theory refers a lot to the study by Galton (1879). Many leaders are superior in terms of intelligence, energy and moral strength than those they lead.

The development of behavioral theory by researchers and psychological scientists is quite influential in leadership theory. This behavioral theory assumes that leaders can be formed; leadership can be developed through a process of learning, observation and experience. Leadership is strongly influenced by personal-situational, thus producing to the interaction-expectation theory that leadership uses three basic variables, namely action, interaction and sentiment. Leadership theory is constantly evolving; Stogdill proposed the theory of expectation-reinforcement (1957), House proposed the theory of motivational leadership (1970), the theory of effective leadership by Fiedler (1970), Argryris, Blake and Mouton developed a humanistic theory which was later developed by Rensis Likert and Douglas McGregor. In addition, the theory of leadership behavior has also developed such as transformational leadership patterns and transactional leadership as proposed by McGreror Burns (1978). The theory mentioned was recently studied by Bass (1985) until it was developed into a separate theory along with models and measurements (Haryono, 2015; Chaniago, 2017; Syahril, 2019).

Leadership models can be matched with leadership styles, because both explain the leadership pattern. Leadership styles have been described by many previous scientists such as positive leadership styles, negative leadership styles, autocratic leadership, participatory leadership, control-free leadership (laissez faire), considerate leadership, structured leadership, contingency leadership (Fidler), situational leadership (Hersey and Blanchard), effective leadership (Leigh and Maynard), managerial grid (Blake and Mouton) which classifies leadership into four namely impoverished leadership, team leader, country club leadership, task leadership and middle of the road (Sagala, 2018; Chaniago, 2017; Sutikno, 2014).

\section{Leadership in Pesantren}

Sagala explained that pesantren must prioritize the quality of responsive pesantren education services through (1) progressive services that is better from time to time by the family, pesantren, and the community, (2) continuous quality management assurance which cannot be achieved immediately. (one shot and quick fix), (3) 
maintaining the quality of pesantren management in a sustainable manner (continuous improvement) by involving various parties in the management and implementation of education in pesantren (Sagala, 2015).

Leadership in pesantren at the end of the 20th century embraced more charismatic leadership. The formal leadership of a pesantren is entirely under the authority of a Kyai. Thus, Kyai has the biggest role for the development of pesantren (Kesuma, 2017; Hasanah, 2020).

Charismatic leadership becomes a model of leadership in pesantren. However, recently, some pesantren have transformed towards adaptive and even democratic leadership (Nazmudin et al., 2017; Wahyuni, et. al, 2016).

Leadership is one of the most important factors in the sustainability of this Islamic educational institution. In its development, Pesantren Ibn Abbas also feels a new attachment phenomenon, namely the increasing love of the middle- and upperclass Muslim community in the last two decades. The enthusiasm of parents to send their children to pesantren is increasing. Of course, this choice comes with 'several' conditions, other than the school is superior, but must meet modern standards in infrastructure (Azra \& Jamhari, 2006).

Parents must be willing to pay more for the facilities and needs at the pesantren. This has become commonplace in today's era. Now it is rare to find students who cook for themselves as in traditional pesantren in the 90s and earlier (Sutrisno, 2017; Wahyudin et al., 2015).

Pesantren in the current era have made a selection both academically and independently to live in boarding schools which is different from the pesantren in the past which accepted those who wanted to study and live in the pesantren. Pesantren has undergone a transformation into a superior educational institution, one of which is a competitive admission process with complete and modern facilities and infrastructure (Azra, 2015; Jamal, 2015; Kadi, 2017; Masroer, 2018).

The typology of leadership in pesantren tends to be transformative leadership and responsive leadership. Basori (2019) recommended that leadership in pesantren (by Kyai) must be able to innovate and carry out institutional transformations to maintain the existence of pesantren and become superior educational institutions in the midst of competition with other educational institutions. Pesantren Ibnu Abbas Klaten manages formal and non-formal educational institutions. However, the highest policy lies on the leader of the pesantren who the Kyai is the holder of power in the pesantren Meanwhile, responsive leadership in pesantren shows the responsiveness of pesantren leaders to the pesantren community, pesantren residents, the needs of santri and the community in general as a necessity (Junaidi, 2018; Basori, 2019; Supendi et al., 2019).

Pesantren Ibnu Abbas Klaten manages formal and non-formal educational institutions. However, the highest policy lies on the leader of the pesantren who the Kyai is the holder of power in the pesantren; However, this Qur'an-based pesantren has developed a syuro-participative leadership model in pesantren management.

The Pesantren's leader is a manager, director, educator, guardian of Islamic values as well as the head of the family apart from being part of the community and citizens. This difficult task will be more effective and productive if the pesantren leader is able to manage it well with an effective management system (Azis, 2017; Fithriah, 2018).

Pesantren Ibn Abbas Klaten, which was established at the beginning of the 21st century, has increased the number of students from year to year, even more than 1000 male and female students.

In the disruption era, the use of technology is not an option but a necessity; especially the students and even the majority of the ustadz Who are the millennial generation. This study is expected to be one 
of the prototypes of the current contextual leadership model and even in the future era. PPTQ Ibn Abbas develops syuroparticipative leadership, why is that? What does shuro-participative leadership mean? How is it implemented?

\section{METHOD}

This qualitative study sought to answer how the pesantren leadership model was and why it was chosen in pesantren management. This study was included into an explanatory study using case studies to uncover and answer the problems posed (Sugiyono, 2017; Yin, 2012).

Primary data were obtained from the location (PPTQ Ibnu Abbas Klaten). The secondary data were obtained from various relevant literatures and previous studies.

Data were collected through observation, interview and documentation related to case descriptions or case themes.

Data were analyzed through interactive models or triangulation models by Miles and Huberman by combining observations and interviews (Miles et.al, 2014; Creswell, 2018).

The findings were then compiled, analyzed, and explained in a narrative manner so that they were arranged into certain propositions and then compiled into theories or theoretical concepts and narratives as novelty.

\section{RESULTS AND DISCUSSION}

Leadership in pesantren is an interesting study for researchers. Pesantren Ibnu Abbas is a boarding school managed by the Islamic Center Ibn Abbas Foundation, Klaten. This pesantren was initiated by three figures, namely Dr. KH. Mu'inudinillah Basry, Lc., MA., Ustadzah Suci, and Ustadz Nurwahid. In its development, dr. Samad joined as a donor and took part in the development of the pesantren.

Ustadz Mu'in had an important role in the pioneering of the pesantren. During the interview by the researcher, the leadership developed at the Pesantren Ibn Abbas is syuro-participative leadership. The statement then becomes a serious concern for the author to examine more deeply about this leadership variant as described follows.

\section{Syuro-Participative Leadership}

As described earlier, pesantren tend to be developed with a charismatic leadership model in which the role of the kyai becomes the main focus in establishing or managing a pesantren. This is natural because in an effort to pioneer a pesantren, the image of a Kyai is very important and influential to gain public trust. However, along with the times, the leadership model is not only based on the charismatic leadership model, transformative and responsive leadership has also developed as an implication of the response to the times, situations and conditions.

There is a process of paradigm shift in the leadership model. The managerial management of the pesantren is not the top down 'only' from and by the Kyai or director. However, more than that the management developed is syuro-participative leadership. This model is quite intrigued by the listeners, isn't there always participation in the syuro?

The author tried to explore the intent of the participatory leadership model idea initiated by Ustadz Mu'in. This graduate of the Doctoral Fiqh wa Ushuluhu from Ibn Su'ud University Riyadh, Saudi Arabia explained that the decision-making system related to all problems, management and development of pesantren is carried out through a deliberation system involving all elements of the pesantren represented by the unit leaders of each pesantren. Thus, there are two key words to understand it, namely "syuro" and "participatory".

The term "syuro" is developed from the Arabic term and is identical with the meaning of deliberation. Syuro is understood as a process of selecting the best ideas from a group of people who are considered capable, have intelligence, competence, good arguments and various solutions to the problems they face or anticipate future problems (Pratomo et. al, 2018; Zein, 2019).

Based on Qs. Ali Imran verse 159, Ustadz Mu'in explained the urgency of syuro. In the 
verse Allah mentions tobe gentle, not rude and the importance of deliberation or syuro. Syuro becomes an institutional process in solving a problem (Mu'in, 2017).

The management of the pesantren develops three pillars of education: the school unit, tahfidz, and santri. The management of each unit is led by the chief . who supervise the optimization of management? All unit chief and leaders attend a meeting every Wednesday where the decisions are made In this forum important decisions are made. The Director really appreciates the participation of all elements. All problems and development of the pesantren are discussed and involve the participation of all elements as representatives. This is the purpose of the syuro-participative.

Each of the above units, apart from being led by the unit chief, is also assisted by several staff that carries out daily operations. The staff in each unit have different competencies and function according to their conditions, situations, and needs. The accountability of each staff to the chef except the finance and human resources (HR) section is centralized to the foundation party.

The main leader of pesantren is the director or also called as kyai. In Pesantren Ibnu Abbas Islamic, the director acts as the mufti as well as the top leader. As a mufti in the pesantren, the director is the primary caretaker, the issuer of regulatory fatwas, and decides the various decisions and policies of the pesantren. However, the decision or policy is made in such a way according to the need level. (Hufron, 2017). This shows how the syuro-participative system continues to be pursued at Pesantren Ibn Abbas.

The top leader in the pesantren is an affirmation of main subject who leads the pesantren organization in its internal and external policies. Ustadz Ali Hufron as deputy director explained that:

The highest decision rests with the director who acts as both mufti and manager while the decisions of subordinates are recommendations to be decided by the director (Hufron, 2017).

Pesantren Ibn Abbas developed a syuroparticipative leadership model. All decisions are resolved in deliberation as needed. The Director holds regular meetings on Wednesday mornings as the author described earlier. This forum is very important; the director is always present and follows the deliberation until finished. Many pesantren decisions and policies that have implications for all pesantren residents are decided at this forum.

The administration at the Pesantren Ibn Abbas has adopted and innovated modern management based on sharia. All financial administration is centralized and there are no cash transactions. All student payments are paid by transfer to the bank account or by a virtual bank account system that has collaborated with the pesantren.

In order to regulate the duties and authorities of each section in the pesantren to serve as a common reference, SOPs (operational standards and procedures) are formulated and applied. All residents must respect and obey the SOP. The SOP at the Pesantren Ibn Abbas pesantren is a basic reference for the pesantren community and all leaders of institutions under the pesantren to be followed, including the Kyai or the director. This is in accordance with the general understanding that SOP is a document related to standards or procedures to carry out and complete an activity or work to achieve performance outputs effectively and efficiently (Sailendra et. al, 2015).

The Director always requests, discusses and consults with all elements of the leadership. Even though the highest decision is the director's prerogative, to the point of being religio-feudal by the kyai, Ustadz $\mathrm{Mu}$ 'in as the director of the Pesantren Ibnu Abbas always conducts deliberation. In fact, more than that, he guarantees a democratic atmosphere and the active participation of all elements.

This shows that the Pesantren Ibn Abbas tends to be more democratic and participatory in deciding policies and various 
pesantren matters. This is different from a study by Sari \& Yani (2013) that the leadership in pesantren in general tends to be religious-feudal where the highest decision is the prerogative of the Kyai (Sari \& Yani, 2013).

Specifically, Fuad Muhammad Zein (2019) identified that syuro is an ideal mechanism for making a decision. Syuro is not only applied to government affairs, it can also be applied to various other social problems. In fact, syuro is elastic and can adapt to the times. The essence of syuro is to respect and maintain human dignity, human nature and maintain harmony. Decisions taken collectively by those who are considered intelligent, knowledgeable, experienced and adhere to Islamic teachings will certainly be better than the decisions of one person alone (Zein, 2019).

Pesantren Ibn Abbas makes the Qur'an as the spirit, the source of teachings and even the true motivation. In fact, the motto of this pesantren is "Success with the Qur'an". Thus, teachings or values from the Muslim holy book become a necessity. This is the basic reason why the leadership model at Pesantren Ibn Abbas uses the syuro system based on the Qur'an.

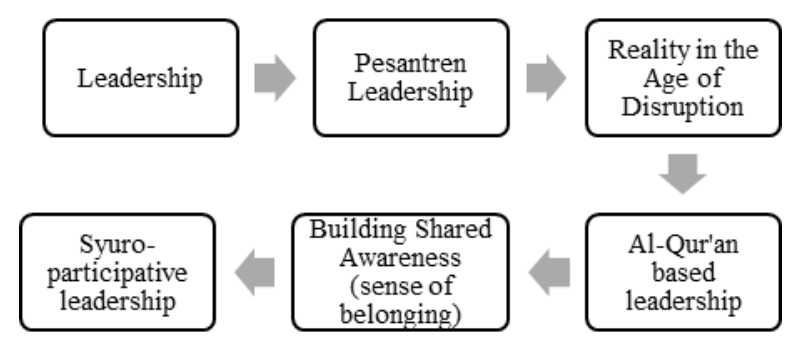

Figure 1

Reconstruction of the Syuro-participative leadership model

The superiority of syuro-participatory leadership is the emergence of a "sense of belonging" from the pesantren academic community because of their great involvement in making decisions from the pesantren. There are similarities with participatory leadership, syuro-participative leadership prioritizes the syuro system rather than just the active participation of the leadership elements. In addition, the management of Islamic boarding schools will always be dynamic with all the problematic challenges they face. However, often Kyai or directors remind the importance of togetherness in solving all problems of the pesantren, so that it will be more effective and productive in the management and development of the pesantren. Kyai at the Pesantren Ibn Abbas acts as a mufti as well as a top leader.

Based on the results, Pesantren Ibn Abbas accepts the development of existing modern management. The banking facilities are chosen because it makes it easier for parents when completing the payments. Another consideration is for the financial accountability of pesantren. A web-based financial information system, meaning that payment information is integrated into the pesantren web with the financial accounts of each pesantren. Several pesantren have also tried to develop the system (Achyar, 2019; Arifin, 2017; Ramadhana et. al, 2020).

Based on the results, pesantren is open to accepting advances and developments in technology, management and all things that bring benefits. However, it is still doing filtering in the implementation. Therefore, the role of pesantren leaders and managers is very important.

\section{CONCLUSION}

Pesantren Ibn Abbas underwent a transformation of charismatic leadership to become more democratic by involving the participation of all elements of the pesantren or their representatives. The implementation of the leadership model in the form of meetings every Wednesday morning becomes very crucial and meaningful.

The advantage of syuro-participative leadership is the emergence of "a sense of belonging" from the pesantren academic community because of their large involvement in taking from the pesantren. Although, there are similarities with participatory leadership, syuro-participative leadership prioritizes the syuro system rather 
than just the active participation of the leadership elements. There is a representative from each unit who is considered capable and able to manage the unit. Kyai at the Pesantren Ibn Abbas acts as a mufti as well as a top leader. Pesantren Ibn Abbas adopts a lot of modern management in the management, publication and promotion of pesantren.

This reinforces a statement that pesantren is open to accepting advances and developments in technology, management and all things that bring benefits. However, pesantren should still be filtering. Therefore, the role of leaders and administrators of pesantren is very important.

Leadership in syuro-participative-based pesantren can be considered in the management of pesantren in this disruption era. This means that pesantren adopts and adapts to all existing developments, but there are still efforts to filter by adjusting to the values, characteristics and principles of pesantren which must be maintained.

\section{REFERENCES}

Achyar, A. (2019). Konsep Manajemen Mutu Terpadu Dan Implementasinya Dalam Pendidikan Islam Studi Kasus di Pondok Pesantren Darul Muttaqien Bogor. Tawazun: Jurnal Pendidikan Islam.

https://doi.org/10.32832/tawazun.v10i2. 1161

Anwas, O. M. (2015). Pemanfaatan Teknologi Informasi dan Komunikasi pada Pesantren Rakyat Sumber Pucung Malang. Jurnal Pendidikan dan Kebudayaan.

https://doi.org/10.24832/jpnk.v21i3.187

Arifin, M. (2017). Manajemen Keuangan Pondok Pesantren. Fikrotuna. https://doi.org/10.32806/jf.v4i2.2745

Aspizain Chaniago. (2017). Pemimpin \& Kepemimpinan (Pendekatan Teori \& Studi Kasus) (Tim LP3I (ed.). Penerbit Lentera Ilmu Cendekia. https://www.kramat.plj.ac.id/download/ Buku Pemimpin \& Kepemimpinan.pdf Azis, A. (2017). Kepemimpinan Kiyai
Sebagai Pemimpin Pendidikan Di Pondok Pesantren Nurulhuda Pekandangan Barat Sumenep. Journal of Islamic Education Manajement.

Azra, A. (2015). Genealogy of Indonesian Islamic Education: Roles in the Modernization of Muslim Society. In Heritage of Nusantara; International Journal of religious Literature and Heritage (Vol. 4, Issue 1).

Azra, A., \& Jamhari. (2006). Pendidikan Islam Indonesia dan Tantangan Globalisasi : Perspektif Sosio-Histori. In Jajat, Burhanudin, Mencetak Muslim Modern: Peta Pendidikan Islam Indonesia (p. 3). PT Raja Grafindo Persada.

Bashori, B. (2019). Kepemimpinan Transformasional Kyai Pada Lembaga Pendidikan Islam. Al-Tanzim: Jurnal Manajemen Pendidikan Islam. https://doi.org/10.33650/altanzim.v3i2.535

Christensen, C., \& Euchner, J. (2020). Managing Disruption: An Interview with Clayton Christensen This is a reprint of Jim Euchner's 2011 interview with Clayton Christensen about managing disruption. Christensen, a pioneer in innovation, died on January 23, 2020.*. In Research Technology Management.

https://doi.org/10.1080/08956308.2020. 1733890

Fithriah, N. (2018). Kepemimpinan Pendidikan Pesantren (Studi Kewibawaan Pada Pondok Pesantren Salafiyah, Modern, dan Kombinasi). Al Qalam: Jurnal Ilmiah Keagamaan dan Kemasyarakatan. https://doi.org/10.35931/aq.v0i0.17

Fuadi, A. (2020). Implementasi Total Quality Managemen di SMPIT Abu Bakar Yogyakarta dan Implikasinya Terhadap Prestasi Sekolah. Literasi (Jurnal Ilmu Pendidikan). https://doi.org/10.21927/literasi.2020.11 (1). $1-10$

Haryono. (2015). Intisari Teori Kepemimpinan. In Journal of Chemical 
Information and Modeling.

Hasanah, S. M. (2020). Pengembangan Pendidikan Agama Islam Melalui Manajemen Lembaga Pendidikan Islam Pondok Pesantren Al-Karomah, Kepanjen Malang. Andragogi: Jurnal Ilmiah Pendidikan Agama Islam. https://doi.org/10.33474/ja.v2i2.9083

Hasibuan (2018:2). (2018). Unsur Manajemen. Adaara: Jurnal Manajemen Pendidikan Islam.

Hermawan, I., Setiadi, D., \& Indrat Wahyuni, H. (2014). Penerapan Ipteks pada Pesantren dan Kelompok Tani pada Masyarakat Lingkar Rawa Pening sebagai bentuk Akselerasi Kualitas Pendidikan dan Keekonomian. Seminar Nasional Teknologi Informasi Dan Komunikasi Terapan.

Jamal, N. (2015). Transformasi Pendidikan Pesantren dalam Pembentukan Kepribadian Santri. Jurnal Pendidikan Islam.

Junaidi, D. (2018). Pengaruh Kepemimpinan Transformasional Kepala Sekolah dan Profesionalisme Guru Terhadap Implementasi Mbs Pada Pesantren di Kabupaten Agam. Islam Transformatif : Journal of Islamic Studies. https://doi.org/10.30983/it.v2i1.437

Kadi, K. (2017). Kesinambungan dan Perubahan Tradisi Salaf dalam Sistem Pendidikan Pondok Pesantren Lirboyo Kediri. Islamica: Jurnal Studi Keislaman.

https://doi.org/10.15642/islamica.2017. 12.1.22-46

Kamil Arif, I., Gunadhi, E., \& Partono, P. (2016). Pengembangan Situs ELearning Dengan Menggunakan Lms Claroline (Studi Kasus di Pesantren Persatuan Islam 96 Banyuresmi). Jurnal Algoritma.

https://doi.org/10.33364/algoritma/v.122.579

Kamus Besar Bahasa Indonesia (KBBI). (2017). Arti kata takut - Kamus Besar Bahasa Indonesia (KBBI) Online. KBBI.

Kesuma, G. C. (2017). Pesantren dan
Kepemimpinan Kyai. Terampil : Jurnal Pendidikan Dan Pembelajaran Dasar.

Komariah, K. S. (2017). Core Value (Ta'āwun Value) in The Development Program of Inclusive Education. Ta'dib (Batusangkar), 20(2), 144-154.

Kristiawan, M. (2015). Telaah Revolusi Mental dan Pendidikan Karakter Dalam Pembentukkan Sumber Daya Manusia Indonesia Yang Pandai dan Berakhlak Mulia. Ta'dib (Batusangkar), 18 (1), 13-25.

https://doi.org/10.31219/osf.io/jd27q

Maghfuri, A., \& Suwadi, S. (2020). Studi Komparatif Pola Pengelolaan Sekolah Islam Berasrama Antara SMAIT Ihsanul Fikri Dan SMAI Al Azhar. Ta'dib, $23 \quad$ (2), 213. https://doi.org/10.31958/jt.v23i2.2369

Masroer, M. (2018). Religious Inclusivism In Indonesia: Study of Pesantren AnNida and Edi Mancoro, Salatiga, Central Java. ESENSIA: Jurnal IlmuIlmu Ushuluddin. https://doi.org/10.14421/esensia.v19i1.1 485

Miles, M. B., \& Huberman, A. M. (2014). Analisis Data Kualitatif: Buku Sumber tentang metode-metode Baru terj. Tjetjep Rohendi Rohidi; Qualitative Data Analysis. UI-Press.

Moleong, L. J. (2015). Medotologi Penelitian Kualitatif (ke-V). PT Remaja Rosdakarya.

Muhadjir, N. (2002). Metode penelitian Kualitatif. Rake Sarasin.

Mustakim, M. (2019). School and Pesantren: Study of Institutional Transformation of Islamic Education in Pesantren-based Schools (SBP) Ibnu Abbas Klaten Indonesia. https://doi.org/10.2991/iccd19.2019 .90

Nazmudin, M. L., Saepulloh, U., \& Sadiah, D. (2017). Peranan Pimpinan dalam Pengelolaan Pondok Pesantren. Tadbir: Jurnal Manajemen Dakwah. https://doi.org/10.15575/tadbir.v2i2.199

Ohoitimur, J. (2018). Disrupsi: Tantangan Bagi Perkembangan Ilmu Pengetahuan dan Peluang Bagi Lembaga Pendidikan 
Tinggi. Respons.

Pratomo, K. T., \& Firdaus, L. Al. (2018).

Sidang Syuro: Melacak Praktik

Community Governance di Masyarakat

Desa Jumo Kabupaten Temanggung.

Journal of Politic and Government

Reyhannisa Erico Dwi Ramadhana, R. E. D.,

\& Fatmawati, A. (2020). Sistem

Informasi Manajemen Keuangan Di

Pondok Pesantren Adh-Dhuha. Jurnal

Teknik Informatika (Jutif).

https://doi.org/10.20884/1.jutif.2020.1.2 .20

Sagala, S. (2015). Manajemen Dan

Kepemimpinan Pendidikan Pondok

Pesantren. Jurnal Tarbiyah.

Sagala, S. (2018). Pendekatan \& Model

Kepemimpinan. Jakarta: Prenadamedia Group.

Sailendra, A., \& Swaest, E. (2015). Langkah-langkah praktis membuat SOP. In Idea Publishing.

Sari, B. I., \& Yani, M. T. (2013). Gaya dan Tipologi Kepemimpinan Kiai di Pondok Pesantren Babussalam Dusun Kalibening, Desa Tanggalrejo, Mojoagung, Jombang. Kajian Moral Dan Kewarganegaraan.

Sugiyono. (2017). Metode Penelitian Kualitatif: Untuk Penelitian yang Bersifat: Eksploratif, Enterpretitif, dan Konstruktif. In Alfabeta.

Supendi, P., Hasanah, A., \& Mahmud, M. (2019). Transformational Leadership in Pesantren on as Sa'idah, Al Matuq, and Sunanul Huda Boarding School. Jurnal Pendidikan Islam. https://doi.org/10.14421/jpi.2018.72.30 3-316

Sutikno, S. (2014). Pemimpin dan kepemimpinan. Pemimpin Dan Kepemimpinan.
Sutrisno. (2017). Implementasi Pendidikan Karakter Di Pondok Pesantren Modern Muhammadiyah Boarding School (MBS) Yogyakarta. Jurnal Elektronik Mahasiswa Pend. Luar Sekolah - S1.

Syahril, S. (2019). Teori-Teori Kepemimpinan. Ri'ayah: Jurnal Sosial Dan Keagamaan. https://doi.org/10.32332/riayah.v4i02.1 883

Ulum, M. (2018). Pembentukan Karakter Siswa Melalui Pendidikan Berbasis Pondok Pesantren. Journal Evaluasi. https://doi.org/10.32478/evaluasi.v2i2.1 61

Wahyudin, U., Arifin, H. S., Studi, P., Komunikasi, I., Komunikasi, F. I., \& Padjadjaran, U. (2015). Di Pesantren Salafi Melalui Pos Kesehatan Pesantren ( Poskestren ) Dalam Membentuk Sikap. Jurnal Kajian Komunikasi.

Wahyuni, S., \& Arifin, Z. (2016). Kepemimpinan Demokratis Nyai Dalam Pengembangan Pondok Pesantren. Journal of Management in Education (JMIE).

Yin, R. K. (2012). Case study methods. In Handbook of Complementary Methods in Education Research. https://doi.org/10.4324/9780203874769 $-11$

Zein, F. M. (2019). Konsep Syuro dalam Perspektif Islamic Worldview. Politea. https://doi.org/10.21043/politea.v2i2.59 10

Zubaidah, R. (2017). Pengaruh Kepemimpinan Kepala Sekolah Dan Kompetensi Guru Terhadap Motivasi Kerja Guru Serta Implikasinya Pada Kinerja Guru di SMP Negeri Kota Palembang. Jurnal Ecoment Global. https://doi.org/10.35908/jeg.v1i2.200 